\title{
Apprentice or Student? The Structures of Construction Industry Vocational Education and Training in Denmark and Sweden and their Possible Consequences for Safety Learning
}

\author{
Regine Grytnes $^{1}$ (D) Martin Grill ${ }^{2}$ - Anders Pousette ${ }^{2}$. \\ Marianne Törner $^{2}$ • Kent J. Nielsen ${ }^{1}$
}

Received: 9 May 2016 / Accepted: 20 April 2017 /

Published online: 28 April 2017

(C) The Author(s) 2017. This article is an open access publication, corrected publication July 2017

\begin{abstract}
There is a notable difference in occupational injury rates in the two Scandinavian countries, Sweden and Denmark, with the latter having a $40 \%$ higher rate of fatal occupational injuries in the construction industry. This study explored differences in the vocational education and training (VET) systems between Sweden and Denmark that may be important for students' safety learning and practice during VET. In both countries, students participate in full-time education, and the curriculum includes school-based as well as company- based training. However, during company- based training Swedish students retain their student status, whereas Danish students are employed as apprentices. From a perspective of viewing safety as a social practice developed through interactions of different social and institutional bodies, the analysis
\end{abstract}

The original version of this article was revised due to a retrospective Open Access order.

Regine Grytnes

regine.grytnes@ vest.rm.dk

Martin Grill

martin.grill@amm.gu.se

Anders Pousette

anders.pousette@psy.gu.se

Marianne Törner

marianne.torner@amm.gu.se

Kent J. Nielsen

kennie@rm.dk

1 Danish Ramazzini Centre, Department of Occupational Medicine, Regional Hospital West Jutland - University Research Clinic, Gl. Landevej 61, 7400 Herning, Denmark

2 Occupational and Environmental Medicine, Public Health and Community Medicine, Academy of Sahlgrenska, University of Gothenburg, Gothenburg, Sweden 
points to this difference in employment status as important for their safety practices and also for the teachers' position to influence safety learning and practices during companybased training. An analysis of interview and survey data focusing on how VET students enact safety 'knowings' across learning sites, suggest how different forms of connectivity models in VET promote various forms of safety learning among students.

Keywords Vocational education and training · Workplace safety · Connectivity · VET curriculum $\cdot$ Mixed methods $\cdot$ Scandinavia

\section{Introduction}

Occupational injuries resulting from unexpected accidents present a challenge to the workforce in Europe. Every year, about 3.2\% of the working population suffer one or more injuries at work (Eurostat 2010). In the construction industry, the figure is higher, namely $4.8 \%$ (ibid). There are significant differences in injury rates across Europe, as well as between the two neighboring Scandinavian countries, Denmark and Sweden. Despite cultural and structural similarities between the two countries, Denmark has a $33 \%$ higher rate of fatal occupational injuries across different occupations. The rate of fatal injuries in the construction industry is about $40 \%$ higher than in Sweden (Tómasson and Gústafsson 2011). Differences were also evident in non-fatal injuries during the construction of the Oresund Bridge and Tunnel, a collaborative project involving Danish and Swedish workers (Spangenberg et al. 2003). Danish workers' injury rate was 3-4 times higher than that of Swedish workers for the same type of work. The study suggested that differences in education and experience, training and learning, and attitude might explain this difference (ibid). The Vocational Education and Training (VET) systems in the two countries are generally described as representing a universalist Nordic model of education, promoting social equality as well as cooperation between the political establishment, the trade unions, and employer organizations (see Busemeyer and Schlicht-Schmälzle 2014; Jørgensen 2015). There are, however, differences between these two systems. Swedish VET is categorized as a school-based system, where the students spend $15-60 \%$ of their time in a training company, whereas Danish VET is a company- based system, where students spend $60-80 \%$ of their time employed as apprentices in a training company (Tynjälä 2009; Jørgensen 2015; Persson and Hallqvist 2014). Differences between the Swedish and Danish organization of VET lend relevance to exploring in greater detail how these differences might influence safety learning of VET students since forms of participation at the workplace have been identified as relevant for apprenticeship learning (Lave and Wenger 1991), and for safety attitudes and practices related to occupational injury prevention (Grill et al. 2015).

The aim of the study reported in this article was to explore how different institutional models of VET may implicate on students' safety learning. The analysis focuses on the following research questions: 1) How are connections between school and companybased training organized within the two models of VET? 2) Who do the students refer to as their primary role model for becoming a tradesperson? 3) Which types of 
'knowings' are enacted at school and at company-based training? 4) How do the findings to questions 1-3 influence students' sense of belonging, occupational identity, and safety learning?

\section{Theoretical and Conceptual Background: Learning Safety}

To investigate these questions, we draw on three different theoretical strands in relation to learning: 1) concepts of connectivity that emphasize the relationship between characteristics of VET in the school and company; 2) concepts of belongingness and occupational identity, drawing attention to social and embodied forms of learning; and 3 ) concepts of the development from novice to expert during VET training. These concepts support an analysis of how particular forms of workplace learning is configured differently within different forms of organizational practices (Gherardi 2006) and thus may translate into differences in students' safety learning.

\section{Connectivity}

Generally, participation in relevant trade-specific communities of practice is seen as a vital component of general learning processes in VET (Bøje et al. 2014; Poortman et al. 2013; Fuller and Unwin 2013) as well as of safety learning more specifically (Grytnes 2017; Gherardi and Nicolini 2002; Nielsen 2012). Integrating knowledge, skills, and attitudes is central to the aim of both school-based and company- based components of VET (Billett 2008; Schaap et al. 2012; Berner 2010; Zitter et al. 2016). Nevertheless, learning across different sites is a profound challenge in VET, as these different institutions (school/ practicing company) have different agendas (Tynjälä 2009). Therefore, acknowledging that school- and practice-based training differ in relation to, for example, the 'understanding of learning' is important (Akkerman and Bakker 2011: 133; Tanggaard 2007; Fuller and Unwin 2013). While some point to the concept of 'transfer' of knowledge from one context to the other (e.g. Aarkrog 2011), Hodkinson and colleagues criticize this perspective for promoting an understanding of learning as 'acquisition', where learning and knowledge are accumulated and installed in the individual in one context (i.e. school) to be used in another (i.e. workplace) (Hodkinson et al. 2008, p. 43). Instead, they propose moving from an understanding of learning as acquisition to learning as participation. Griffiths and Guile (2003) understand learning as a process in which the development of "the capability to mediate between different contexts, rather than simply bringing their accumulated vertical knowledge and skill to bear on the new situation" (p. 61) is at stake. This process is referred to as 'resituation' (ibid, 66). The connective model of learning developed by Guile and Griffiths (2001) aimed at developing a more connective relationship between theory and practice involving thinking, dialogical inquiry, boundary crossing, and resituation (Hodkinson et al. 2008).

\section{Belongingness and Occupational Identity}

In relation to safety learning practices among Danish and Swedish carpentry students, an exploration of how knowledge is used within different models of connectivity is therefore relevant. Issues of status and role during school training and workplace 
training are important. Lave and Wenger's theory of legitimate peripheral participation in a community of practice has had a profound influence on our understandings of learning as participation (Lave and Wenger 1991). Learning is not only a cognitive process; it also "implies becoming a different person with respect to the possibilities enabled by these systems of relations" (Lave and Wenger 1991, p. 53). Along the same lines, Chan (2013) states that" enactment of apprenticeships is more than the development of a set of occupational skills" (p. 369). Learning is a form of induction to working life accompanied by the formation of occupational identity through ongoing participation in social practice (Billett 2008).

However, exactly how learners participate has been debated (Fuller and Unwin 2003; Hodkinson et al. 2008; Gherardi 2010). The question is whether learning takes place through participation while adjusting to a pre-given context or, as Hodkinson and colleagues propose, whether learning occurs through a learning culture where learning is constructed and reconstructed through the forces of one or more fields (Hodkinson et al. 2008). In this way, individuals influence and are part of learning cultures, just as learning cultures influence individuals (Hodkinson et al. 2008, p. 37). Hodkinson and colleagues focus on individual learning within a broadly situated or socio-cultural perspective, i.e. embodied learning. Instead of framing this as a question of identity, they use the concept "learning as becoming" (Hodkinson et al. 2008, p. 40), arguing that identity is too wide a concept as it covers aspects other than learning.

From a practice theoretical orientation, Gherardi advances the argument that the concept of 'belongingness' to a community implies a shift in the understanding of learning. Viewing communities as 'real' context for practice, she understands practices as "a form of learning and practical knowledge as a situated activity" (Gherardi 2010, p. 515). Knowledge, therefore, is not an 'asset' of the community (or the individual, for that matter), but rather an activity, 'a knowing', that itself constitutes the practice. From this perspective, safe working practices in VET are learnt as practice, involving situated and interrelated learning, not as transfer of knowledge from school to work.

Education and training have been suggested as effective means of influencing attitudes and practices in relation to safety at work (Gherardi and Nicolini 2002). The effectiveness of safety education programs has, however, increasingly been questioned, as it cannot be assumed that knowledge about safety automatically transfers into safe practices (Somerville 2006; Pisaniello et al. 2013; Bieder and Bourrier 2013). Gherardi argues therefore by asking questions on how safety as a practice is conceived and transmitted through organizational practices (Gherardi 2006). As VET takes place in more than one community, transforming knowledge from one community to the other and back again is a complex process (Taylor and Freeman 2013). There arises the need to develop questions based on our knowledge of the complexity of learning.

\section{Moving from Novice to Expert}

The aim of VET is to educate students to enter into skilled jobs, for instance, in the construction industry. It is therefore appropriate to focus on how the transition from novice to expert is modelled in a workplace-based educational program. Drawing on the classic study by Dreyfus and Dreyfus (1986) which points out that transition from novice to expert is a lengthy process, Murtonen et al. (2009) allude to the importance for students to approximate the practices of experts in order to become experts 
themselves. However, they found school and practice based company training to be disconnected, as the school depends on 'idealized models' of describing work. The use of 'scaffolding rules'; i.e. rules" taught to students but not really used in authentic work situations" was found to be a hindrance for practical learning instead of assisting it (Murtonen et al. 2009, p. 109). Different VET systems may promote different forms of connections between school and company based training which provide a range of organizational contexts for transition from novice to expert. The following analysis explores learning as promoted through connections and disconnections between school- and training-company, and views learning as participation and resituation in different contexts. Learning, might thus not be a question of idealized versus actual practices, but about how students learn to deal with ideals in practical work. Knowledge is thus not viewed as an asset of the individual or the community (school or practicing company), but rather as an activity across learning sites (Gherardi 2006). Drawing on the framework of becoming an expert within a connective understanding of learning lends relevance to exploring how different 'knowings' are enacted and how 'idealized practices' and 'scaffolding rules' could explain some of the complexities of safety learning.

\section{Material and Methods}

The study was part of a joint Swedish and Danish research program. The overall aim of the program was to identify causal factors behind the difference in the rate of occupational injuries in the construction industry in Denmark and Sweden. As the specific aim of this study was to explore the differences between Swedish and Danish institutional models of VET and how these may translate into safety learning among carpentry students, we applied a mixed-method strategy (Bryman 2004), combining quantitative and qualitative methods (see Creswell 2003; Tashakkori and Teddlie 2010). The quantitative and qualitative data were collected sequentially (Bryman 2006).

A document study, including analysis of laws and regulations relevant to both education systems, was carried out using content analysis. This involved focusing on themes identified in the literature and issues related to health and safety in the VET programs. By incorporating a cultural and situational understanding of VET as a complex organizational practice acted out in the interrelationship between the individual, the institutional, and the social level, the document analysis contributed to answering research question 1 on how connections between school-based and company-based training were organized and situated within the two models of VET.

A questionnaire was then completed by students at Danish and Swedish vocational schools to determine students' notions of school and training companies. The analysis served to answer research question 2 on identifying the students' primary role model for becoming a tradesperson, and part of research question 4 on how this influences students' safety learning.

The questionnaire data informed a subsequent qualitative field study that was conducted with students and teachers at the vocational schools. Data from both focusgroup interviews and individual interviews were analyzed to explore research question 3: Which types of 'knowings' are enacted at school-based and at the companybased training? as well as question 4: How does this influence students' sense of 
belonging, their own occupational identity, and their safety learning? The purpose of this study was to explore how different 'knowings' about safety and notions of belonging and becoming were enacted across the school/training company divide. Coding was conducted with the aim of exploring the relations between the different parts of the study, focusing on the experiences of school/training company connectivity, on the students' role in the companies, as well as the teachers' connective practices.

The mixed methods design facilitated an understanding of institutional differences (and similarities) relevant to safety learning. Different types of data from various sources supported the analysis of school/training company connectivity within the two institutional models and indicated how they may influence safety learning.

\section{Document Study and Analysis of Relevant Regulation}

Laws and regulations, as well as documents from the government organizations and from the institutions (represented by the stakeholders to the labour market) controlling the quality of VET education, were analyzed. Sweden and Denmark have pursued different avenues for public and employer involvement in VET (Jørgensen 2015). Based on this and on Busemeyer and Schlicht-Schmälzle (2014) models on diverse VET systems with varying degrees of public and employer involvement, special focus was placed on the role of the state, the organization of workplace training, and the status of students. In the Swedish case, the documents chosen were the Education Act (2010), documents and websites from the Swedish National Agency for Education (Swedish National Agency for Education 2011), and documents from the Swedish Construction Industry Training Board (Training Agreement between the social partners 2006). In the Danish case, the documents to be analyzed were the Vocational Education Act (2013), the website Guide on Education from the Ministry of Education's information and guiding agency, and documents from the Advisory board for Education and Training for the Building and Construction Industry. The materials were selected on the basis of their inclusion of statutory material and those from the industry/unions of relevance to VET and safety learning.

\section{Participants}

The study was conducted at three Danish and four Swedish vocational schools. The three Danish schools were located in the middle and northern parts of Jutland, and the Swedish schools were located in the Western Götaland region. The schools were strategically selected to represent a larger city as well as smaller towns in both countries. All VET students from the construction divisions of the schools were invited to participate in the study $(n=1561$; Denmark: 839; Sweden: 722$)$. The specific vocational divisions were carpentry, plumbing, painting, bricklaying, earth work, concrete work, and metal work. A total of 1305 students (Denmark: 701, Sweden 604) completed the questionnaire, $94 \%$ of whom were male (see Table 1). As the study explored students' perceptions of differences between the school and their workplace training company, the analysis included only the 557 Danish and 403 Swedish students who had experienced company-based training. This excluded 144 Danish and 201 
Table 1 Participants in the questionnaire study

\begin{tabular}{lll}
\hline & Denmark & Sweden \\
\hline No of Schools & 3 & 4 \\
No of students - all & 701 & 604 \\
No of students - with company-based training & 557 & 403 \\
Response rate - all (\%) & $84 \%$ & $84 \%$ \\
Age all (range) & $22.5(17-52)$ & $18.4(17-22)$ \\
Age with company-based training (range) & $22.8(17-52)$ & $18.8(17-22)$ \\
Male all (\%) & 93 & 94 \\
Male with company-based training (\%) & 93 & 93.0 \\
\hline
\end{tabular}

Swedish 1 st year/basic course students. There was a difference in the age distribution as Swedish students were on average approximately 4 years younger than the Danish students. While all Swedish students were aged 17-22, a third of the Danish students were over 22 years of age. This reflects the different structuring of VET education in Sweden and Denmark (see below).

\section{Questionnaire}

Questionnaire data were collected in the vocational schools during the spring of 2014 and were completed in the classroom during school hours with members of the research team present.

The questionnaire included four measures of relevance to the present study. The first two, Safety climate (teacher) and Safety climate (training company supervisor) included five items each, taken from the subscale 'management safety priority and ability' of the Nordic Occupational Safety Climate Questionnaire (NOSACQ) (Kines et al. 2011). The items were adapted to measure the students' perceptions of their teachers' prioritisation of safety at school and their supervisors' prioritisation of safety at practicing companies. Sample item: "The teachers/supervisors encourage us to work in accordance with safety rules - even when the work schedule is tight". A 6-point response format ranging from 1 (Not at all correct) to 6 (Completely correct) was used for these two measures. The third measure, School/training company discrepancy, consisted of five items measuring the degree of perceived connection and interrelatedness between what is taught at school and how work is actually performed at the training company. Sample item: "Do you perform work tasks at your training company in a different way than what you have been taught as the correct way at school?", a 7point response format from 1 (Never) to 7 (Always) was used. Average scores for each scale were calculated.

In the fourth measure, the students were asked to Rank 6 different persons/categories of persons ('Teachers at school', 'Supervisor in the training company', 'School mates', 'Co-workers at the training company', 'Manager at the training company', and 'Parents or other close relative') who made important contributions to the student's development as a skilled tradesperson. The most important person/category was assigned rank 1, and so forth. Rank means for each person/category were calculated.

Independent samples t-tests were used to compare means between the Danish and Swedish respondents regarding Safety climate (teacher and on-the-job supervisor) and 
school/training company discrepancy. The non-parametric Mann-Whitney U test was used to compare the ranking of the importance of the six different persons/ categories between the two countries. All tests were performed using SPSS v. 20.

\section{Participants and Recruitment for Qualitative Study}

The qualitative study was carried out at the carpentry divisions of the three Danish schools and three of the Swedish schools during the autumn of 2014 and the spring of 2015. Carpentry was chosen because it is one of the major divisions in both countries, and carpenters occupy a variety of positions in the construction industry.

Two members of the research team (one Swedish and one Danish researcher) conducted all observations and interviews at the schools, the first author being present across all the school field studies. Two or three days were spent at each school. During the first day, observations of one or two classes were conducted on the school shop floor; and during days two and three, the researchers alternated between observing practice on the shop floor and interviewing teachers and students, individually or in focus groups. All interviews were conducted in participants' mother tongue. The researchers took field notes during observations and revised and elaborated these notes collaboratively after each observation. The interviews and observations at the schools are summarized in Table 2.

For the interviews, students were either recruited by the principal/deputy manager or by the teachers, or they volunteered at the request of the researchers during observations on the shop floor. The teachers were either recruited for the interviews in advance by the school planner or alternatively during the observations by the research team.

\section{Observations and Interviews}

Observations focused mainly on shop floor classes where students worked on particular tasks, alone or together with other students. In Sweden, first-year classes were observed because they are the only ones to have shop floor practice. In Denmark both first-, third-, and fourth-year classes were observed. We focused on communication between teacher and students, comments from the teachers about safety or safety-related issues in the class, and on the task at hand. In one instance, we observed the health and safety classes in a Danish school, both during theoretical instructions and practical exercises in the handling of machines. It was not possible for us to observe these classes in the other Danish schools as they were scheduled for times when we could not be present. In Sweden, health and safety is not taught in specific classes but are integrated into other subjects.

The interview guide for student focus groups was developed on the basis of the results from the questionnaire to explore different experiences and attitudes among students. The interviews aimed to explore the students' understanding of their role at the training companies, focusing on their interactions with managers and experienced colleagues at the training companies. Another aim was to explore their understanding of the teachers' role in relation to the organization of company- based training. The 
Table 2 Interviews and observations at schools

\begin{tabular}{|c|c|c|c|c|}
\hline School & $\begin{array}{l}\text { Student focus } \\
\text { groups interviews }\end{array}$ & $\begin{array}{l}\text { Teacher interviews } \\
\text { and focus groups }\end{array}$ & Observations & Days \\
\hline SweOne & $\begin{array}{l}1 \\
1 \text { st, } 2 \text { nd, 3rd year (3 students) }\end{array}$ & $\begin{array}{l}1 \text { ( } 2 \text { teachers in } \\
\text { focus group) }\end{array}$ & 1st year students on shop floor & 2 \\
\hline SweTwo & $\begin{array}{l}3 \\
1 \text { st, } 2 \text { nd, 3rd year } \\
\text { (7 students) }\end{array}$ & 3 individual & $\begin{array}{l}\text { 1st year students' building site } \\
\text { on school premises; participation } \\
\text { in network meeting }\end{array}$ & $21 / 2$ \\
\hline SweThree & $\begin{array}{l}2 \\
1 \text { st, } 2 \text { nd, } 3 \text { rd year } \\
\text { (5 students) }\end{array}$ & 2 individual & 1st year students on shop floor & $21 / 2$ \\
\hline DanOne & 1st and 3rd year (6 students) & $\begin{array}{l}2 \text { (1 individual and } 1 \\
\text { focus group with } \\
2 \text { teachers })\end{array}$ & $\begin{array}{l}\text { 1st and 3rd year students on } \\
\text { common shop floor, and } \\
\text { in machine workshop }\end{array}$ & 3 \\
\hline DanTwo & $\begin{array}{l}1 \\
3 \text { rd year } \\
\text { (3 students) }\end{array}$ & 2 individual & $\begin{array}{l}\text { 3rd year students on shop } \\
\text { floor, HSE in classroom }\end{array}$ & 3 \\
\hline DanThree & 1 st and 3 rd year (6 students) & $\begin{array}{l}2 \text { (1 individual and } 1 \\
\text { focus group } \\
\text { with } 2 \text { teachers })\end{array}$ & $\begin{array}{l}\text { 1st year on shop floor and HSE } \\
\text { class room, 3rd year shop floor }\end{array}$ & 3 \\
\hline Total & 11 (30 students) & 12 (15 teachers) & $\begin{array}{l}8 \text { classes in total. 1st year classes } \\
\text { observed in Sweden 1st and 3rd } \\
\text { year classes observed in } \\
\text { Denmark. }\end{array}$ & 16 \\
\hline
\end{tabular}

interview guide for the teacher interviews focused on their notion of the students' role in the training companies, and their views on differences between school and training companies, focusing on the teachers' role in relation to the companies, and their supervision of the students during company-based training.

In this article, we draw primarily on the interview material, and the observation notes, used as context, to explain the overall analysis.

\section{Analysis}

All interviews were transcribed verbatim and the data was analyzed using Nvivo10 software program. Coding and analysis were performed iteratively in collaboration with all the authors. We did not use blind coding for the qualitative data, but read the material several times in order to refine and adjust our understanding and enhance the interpretive and theoretical validity (Norris 1997). Themes from the interview guide were initially used to code the material, while we stayed attentive to the emergence of new themes. During this process, an understanding of the implications of the two models of VET education for safety learning emerged. Notions of belonging to the company, and the implications of this for safety learning, ultimately guided the final analysis. A socio-cultural approach was applied that considers safety as an integral part of the social activities of a community of practice (Gherardi et al. 1998b; Gherardi and Nicolini 2002; Lave and Wenger 1991). This perspective directed the analysis towards relations between the different communities of practice that the students were part of and their identification with and sense of belonging to these (c.f. Gherardi et al. 1998a). 


\section{Results}

\section{Document Analysis}

\section{Sweden}

In both Denmark and Sweden, vocational training takes place at the upper secondary level of the educational system. In Sweden, the upper secondary level is a three-year unified one-track system for young people, aged 16-19 years, whereas older students' education is organized as adult education programs (Education Act 2010; Jørgensen 2015; Busemeyer and Schlicht-Schmälzle 2014). Twelve of the 18 national educational programs are vocational programs. VET is governed by the Education Act administered by a central administrative authority for the public school system (Education Act 2010). To ensure transparency, an Advisory Council without legal authority is appointed to the National Agency for Education by the government. The actual content of specific programs in upper secondary education is regulated by government-issued curricula.

The first year in Swedish VET is almost exclusively spent at the vocational school within the branch-specific program. Toward the end of the year, the students choose a specialty. In the second and third years, students typically spend two to three days a week at school attending theoretical classes, and two to three days at the training company. VET students in Sweden obtain student allowances from the state for the entire duration of the VET. During company- based training students are compensated for work clothes and lunches. Swedish vocational education students are not employed as apprentices in a company, but work in the company as student workers. Students may either find a practicing firm themselves; alternatively, the school or teachers arrange training companies for them. Firms with a union agreement are preferred for VET education, as this allows the students to be credited with the hours spent in training companies. These hours are included in their qualification documentation for a professional certificate. It is only upon completion of the three years of upper secondary education that the Swedish VET students may start apprentice employment. All students at the vocational programs in Sweden may attain higher education. However, since trade-specific courses take up time that in academic programs is allocated to theoretical studies, VET students first need to supplement their training with additional theoretical courses (Education Act 2010).

The school and the training company have joint responsibility for the health and safety of the students during company- based training (Responsibility for the pupils' work environment 2013). The school is therefore also responsible for students during company- based training and must monitor the work environment at the training company as well as review safety routines (ibid).

\section{Denmark}

Unlike other Nordic countries, Denmark has a dual-track upper secondary education system. It is divided into a track for education that qualifies students for access to higher education, and a track for vocational or technical education that qualifies students for entrance to the professional labor market (Juul and Jørgensen 2011; 
Jørgensen 2015). VET is regulated by laws issued by the Ministry of Education. The Ministry is advised by the Council for Vocational Training, which consists of representatives from the trade unions and employer organizations. In addition, so-called Trade Committees, set up by employers and employee organizations, are responsible for formulating the precise content of the trade specific programs and for governing of the final exams (Vocational Education Act 2013).

In Denmark, ${ }^{1}$ education for most construction specialties normally takes four years to complete. The first 20-40 weeks consists of a basic course. Upon completion of the basic course, the students are obliged to secure employment as an apprentice with a training company or, if they are not able to do so, apply for a limited number of schoolbased training programs. For about 3.5 years, education alternates between periods at school and more extensive periods of on-the-job training in a company (Vocational Education Act 2013). During the main part of the education, the student/apprentice works with a company as an employee and receives a salary, which they also receive while they attend school. The training companies are economically compensated for the school-based periods. Upon completion of vocational education, success in the final exams result in the issuing of a vocational work certificate, and the student is thereafter a certified tradesperson, eligible for fully paid skilled work. Education at the vocational school does not normally qualify for further education (except education as a construction architect and certain other technical specialties). Since 2011, it has, however, been possible to obtain both a professional certificate and a higher education entrance qualification within the vocational education system.

Danish apprentices are employed in a company, and under Danish law the employer is responsible for the planning, organization, and performance of the work in accordance with health and safety regulations. The employee should contribute to keeping working conditions safe, use the safety equipment provided and report if they encounter unsafe issues. During VET professional training the Boards are responsible for the content of the education set out in the legislation and for issuing training company approvals. The schools, in partnership with local Training Board set out the specific curriculum and the Training Boards check on and approve the student log books specifying the level of expertise in different subjects obtained in the training company. During school-based training, a health and safety training course is obligatory. Only certified health and safety teachers teach this course, and it corresponds to an industry-wide standardized health and safety representative training course. The main differences between VET institutional models in the two countries relate to the degree of state/public and company/employer involvement, health and safety responsibility and education, and in the status of the students when participating in company- based training. The main differences are summarized in Table 3.

\section{Survey Findings}

The results from the questionnaire study identified salient features of student learning to become a professional, and potential role models for safety practices. The results showed that Swedish students perceived a higher safety climate among training

\footnotetext{
${ }^{1}$ In 2015, a new VET reform was implemented in Denmark, but the documents referred to in this analysis refer to the VET system under the previous regulation, since data collection ended before the reform was implemented.
} 
Table 3 Differences between the Danish and Swedish institutional models related to VET in construction

\begin{tabular}{|c|c|c|c|c|}
\hline & $\begin{array}{l}\text { State } \\
\text { involvement }\end{array}$ & $\begin{array}{l}\text { Employer/ Company } \\
\text { involvement }\end{array}$ & Health and safety & Student status \\
\hline Sweden & High & Low & $\begin{array}{l}\text { Joint responsibility (school/ } \\
\text { company), integrated courses }\end{array}$ & Student allowance \\
\hline Denmark & Low & High & $\begin{array}{l}\text { Training company responsibility, } \\
\text { specific course }\end{array}$ & Apprentice employment \\
\hline
\end{tabular}

company supervisors $(\mathrm{t}(919)=7.12, p<0.01)$ than the Danish students. No difference was found regarding students' perceptions of teacher-related safety climate $(\mathrm{t}(940)=-1.53, \mathrm{~ns})$. In both Denmark $(\mathrm{t}(527)=15.22, p<0.01)$ and Sweden $(\mathrm{t}(387)=3.52, p<0.01)$, teacher-related safety climate was ranked higher than company supervisor-related safety climate, indicating a higher priority for safety in the schools than in the training companies (see Table 4).

Danish students reported a higher school/training company discrepancy than their Swedish counterparts $(\mathrm{t}(930)=-9.27, p<0.01)$, indicating that they perceived a greater disconnection between what is taught at school and how work is performed at the training companies.

Figure 1 shows the mean rank of the 6 persons/categories regarding perceived importance to students' efforts at becoming skilled crafts persons. There was a significant difference in the ranking between the two countries regarding Teachers $(\mathrm{U}=113.530, p>0.01)$ and Training company management $(\mathrm{U}=80.718, p<0.01)$. Parents or other close relatives $(\mathrm{U}=118.282, p<0.01)$ and friends at school $(\mathrm{U}=84.152, p<0.01)$ also differed in rankings between the countries, but were ranked as least important in both countries. In Sweden, teachers were ranked as the third most important group, while top management was fourth. In Denmark, the opposite was found, with top management ranking third and teachers fourth.

\section{Interview Findings}

\section{The Swedish Schools}

The Swedish students described company- based training as being more relevant than school shop floor training. In one of the student focus groups, the

Table 4 Differences between Danish and Swedish students

\begin{tabular}{|c|c|c|c|c|c|c|c|}
\hline & \multirow[t]{2}{*}{ Alpha } & \multicolumn{2}{|c|}{ Denmark } & \multicolumn{2}{|c|}{ Sweden } & \multirow{2}{*}{$\begin{array}{l}\text { Diff } \\
(\mathrm{S}-\mathrm{DK})\end{array}$} & \multirow[t]{2}{*}{ Cohen's d } \\
\hline & & $\mathrm{n}$ & Mean (SD) & $\mathrm{n}$ & Mean (SD) & & \\
\hline Safety climate, Teacher & 0,79 & 543 & $4,68(0,86)$ & 399 & $4,59(0,81)$ & $-0,08$ & 0,10 \\
\hline Safety climate, Supervisor & 0,84 & 532 & $4,00(0,90)$ & 389 & $4,42(0,87)$ & $0,42 *$ & 0,47 \\
\hline School/training company discrepancy & 0,80 & 543 & $4,38(1,00)$ & 359 & $3,74(1,12)$ & $-0,65^{*}$ & 0,60 \\
\hline
\end{tabular}

$* p<0,01$ 


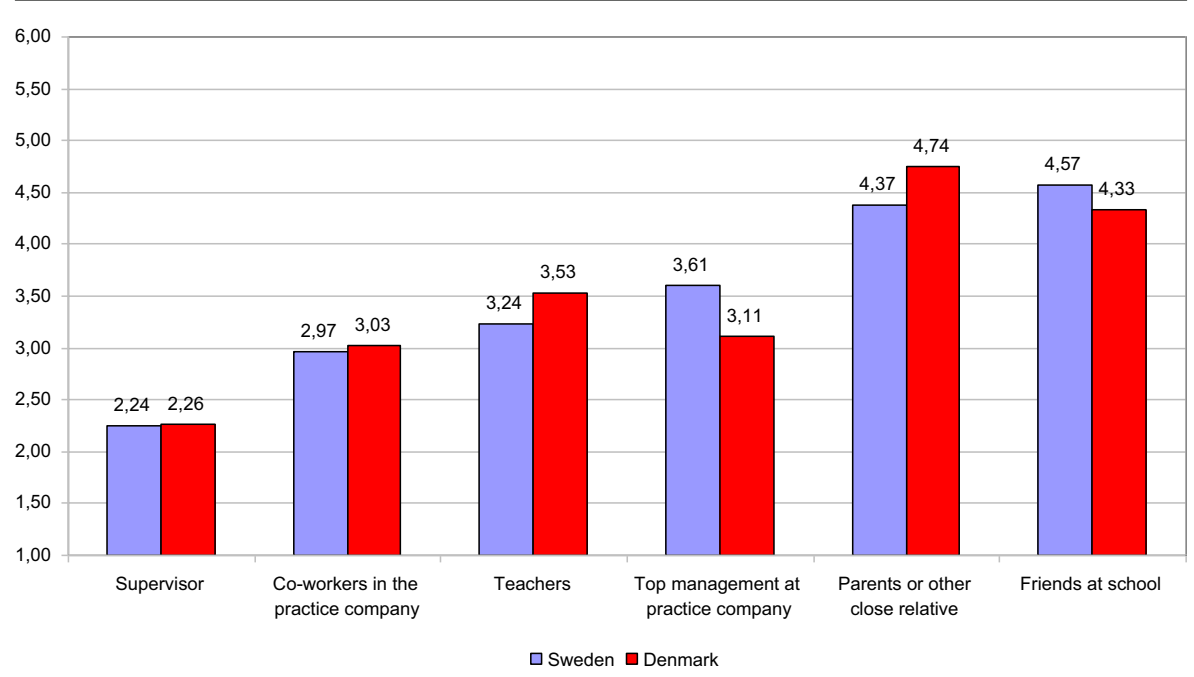

Fig. 1 Mean rank of perceived importance of groups/persons to students becoming skilled tradesmen (Range 1-6, where 1 implies the highest rank)

difference between school-based and company-based training was described in the following way:

Swedish student 1: [At work] we see how it is done in real life.

Swedish student 2: It is real life... you learn more.

Interviewer: What do you mean, you learn more?

Swedish student 2: You catch on to things more easily.

Swedish student 1: You try things, and then learn.

Interviewer: What about in school?

Swedish student 2: We're building garden shed after garden shed after garden shed.

This description exemplifies a notion of learning as linked to practical work where things are made to be used in real life, and with variation in the tasks. This is contrasted to the building of garden sheds which the students experienced as poorly simulating real building processes, and where they seldom faced new challenges. In the training company, they participated in 'real life' work. This was linked to motivation and a form of learning that the schools did not provide. In the shop floor observations, we noted how teachers did not consistently comment on potential unsafe behaviours, such as use of electrical tools, but also how risk assessments were part of student evaluations at the end of each lesson.

The Swedish students stated that teachers' instructions and introductions to the use of safety equipment resembled that of their co- workers at the training companies. In 
the interviews, their training company colleagues were described as very conscientiously using, for example, ear protection when working.

Taking part in daily practices in the training companies sometimes involved tasks that the Swedish students felt uneasy about. When asked how they reacted when they encountered unsafe working practices, most of them described their right to voice feelings of unease, also when their feelings conflicted with their co-workers' or managers' understanding. One of the Swedish students described the following experience where he had refused to do a certain job because he felt uneasy about walking on a roof:

Swedish student 3: But if they ask me to get something on the roof, I tell them 'I won't do it'.

Interviewer: How do they react?

Swedish student 3: They'll go and get it themselves. They will have to do that all the time. I won't do it later either. They will have to do it themselves.

Interviewer: And why don't you want to do it?

Swedish student 3: Because I don't like walking on the roof, so they'll have to do it themselves.

Interviewer: What if you have work to do on a roof?

Swedish student 3: Then they'll have to put up a proper scaffold around the building, so I can go up, or else I won't.

Refusing to engage in certain tasks was described as a legitimate and natural right by the Swedish students. In this quote, the student's own sense of risk is referred to as knowledge that demands safety precautions. In this sense, 'scaffolding rules' here is backed up by a notion of everyone's right to say 'no'.

With regard to potential difficulties and conflicts between the students and training companies, Swedish students identified the teacher as someone who checked up on and took responsibility for both the school-based and company-based parts of the study program. The teachers were described as being concerned with their safety, as the following quote illustrates:

Interviewer: Can you talk to the teachers about whether you feel safe or not?

Swedish student1: If you don't like it there anymore, or yes, if you are uncomfortable with your workmates, things like that, you can talk to him about that.

The Swedish teachers voiced a sense of responsibility for the well-being and learning environment of their students during the periods of company- based training. We observed differences between schools in terms of the frequency of teachers' 
supervision of company-based training, but in the interviews they emphasized their obligation to monitor the students' company training. One of the Swedish teachers described his role as the 'students' advocate' in relation to the training company, a role that is also evident in the following quotation from one of the other Swedish teachers:

If it happens that the student feels insecure about his supervisor in the training company, and the student feels that he is pressurized into doing things that he doesn't feel comfortable doing, I generally say to the students, 'If so, you should call me, and I will come straight away'. Then I go out there and talk to the supervisor. He should not do these things, and as teachers we need to take responsibility for the situation and to take care of the student.

The role of advocate did, however, pose a dilemma for teachers as their authority pertained to the student in the company- based training setting and not to the company as such. They stated that they could suggest improvements to safety standards and practices. However, they also saw the need to maintain good relations with the companies in their district in order not to create conflict or negative attitudes. If a student's safety was jeopardized, they might, however, remove the student from the company and prohibit that company from getting new students. In this way, teachers contributed to the selection of suitable companies for company- based training contracts. Occasionally, students were matched with firms that had no former record of having students; this was described as a process of "testing out" to see how it worked "for the student to be satisfied, the company to be satisfied, and also so that I am satisfied", as one of the teachers put it. Swedish teachers stressed their responsibility to ensure that company- based training was in keeping with the curriculum, as the following quote from one of the teachers illustrates:

Some firms only want to have a worker, and when the particular job is finished the student is sent back to the school. And then, after a while they call again. But they have no regard for pedagogical considerations; they see the students only as workers.

Overall, the Swedish VET students are recognized as a specific category in relation to safety precautions. Their role stands out from the roles of the other workers at the building site; they need 'scaffolding rules', underpinning the educational rather than the company perspective.

\section{The Danish Schools}

Danish students identified their participation in training companies as allowing them to acquire practical knowledge of how things are done. When it came to safety knowledge, however, they referred to their teachers as their main source of knowledge. Moving between different learning sites was described by the students as highlighting different forms of knowing and learning, and students 
identified differences in opinion about safety as a potential dilemma for apprentices. One of the students described the following scenario:

We used gypsum boards, which I had never worked with before, even on the basic course. It meant that I wasn't very good at it and, second, it produced a lot of dust from the insulation. So I was like coughing all the time and I complained about it, and asked for a mask several times. They got tired of me, but I wouldn't go on working like this. But I am sure that some people would just put up with it because they want to keep their apprenticeship.

In this situation the student claimed his right to personal protection, but he link his behavior to a risk of loosing his apprenticeship and thus link safety learning to the issue of keeping good relations with the training company. Several Danish students explained they felt that safety was an economic burden for their employer. The need for safety equipment was often framed as an expense. "It is his (the employer's) money", as one of the students put it, expressing loyalty toward company priorities.

Also, an understanding of safety as being the students' own responsibility was expressed. The students saw this as being the case at school as well as in the training companies, as indicated in this quotation:

Interviewer: Do you see any differences between safety at the school and the training company?

Danish student 3: No, not really. You have to have your safety shoes and the tools must function. You have to wear the protection gear. But, it is up to the individual whether to use the protection gear or not (...). We are adults, after all.

In this interview, the question of the use of safety equipment was referred to as something natural and obvious. However, at the same time it was linked to an experienced worker's own judgement. This suggests that the students saw themselves as responsible company workers who had the right and responsibility to take care of their own safety.

At the same time, if they had concerns about certain risky tasks, students claimed their right to voice their opinion. Both their employers and their teachers told them to "take care of themselves", as a way of taking care of their own safety. However, "being a total rule freak "was described as a way of losing influence in the training company, suggesting that a concern with 'scaffolding rules' would hinder them from full participation. At the same time, several of the students told us that even though they had performed unsafe tasks at the beginning of their apprenticeship, they had started to question the decisions of the employer or colleagues in the training company as they became more experienced.

Teachers also described training companies as places where the students could expect to work with people who were not following safety rules and, more importantly, as places where co- workers had no specific responsibility for the students' safety. The teachers considered themselves unable to influence the students way of working in the training- company. Also, Danish teachers identified a lack of connection between the school-based and company- based parts of the education. One of the teachers explained 
the relationship between the two communities of practice within VET in the following way:

We arrange open visits when the employers can come and visit the school, so they can see what the students work with at school, but few of them show up. Apart from that, our only contact with the employers is when there is some problem and we have to cooperate around the student. Otherwise, we have no contact. (...) There is a deep division between school and workplace in Denmark.

The teachers referred the students to trade unions if they needed help to solve problems at the training company. The teachers described their ability to act on safety-related issues during company- based training as minimal since students are employed apprentices in the company. This resembles the students' understanding that their employer is the one to turn to should problems occur.

Several of the teachers referred to the training companies as representing a challenge when fulfilling the educational curriculum regarding safety because the school had no way of influencing either company practices or their students' practice in the companies. At the same time, they acknowledged the decisive role of company- based training in relation to the students' professional qualifications. As such safety learning and professional learning are portraited as separate forms for learning. One of the Danish teachers expressed it in this way:

I think that the workplace is valued higher than the school. Generally, you can say that in school they learn what they need for their certificate, but what they learn out at the workplace is what they're going to draw on for the rest of their lives.

This indicates that connectivity in the Danish VET model is enacted in different ways in the school-based and training company-based parts of the education. Different knowledges are enacted, albeit the students referred to 'taking care of themselves' as a form of knowing that is relevant in both learning sites.

\section{Discussion}

Students' notions of connectivity with regard to safety learning were explored in the questionnaire data. These data showed no differences in the teacher-related safety climate between the Danish and the Swedish schools. However, Swedish students reported a higher safety climate in the training companies than did the Danish students. There can be several explanations for this. A joint responsibility for health and safety means that Swedish teachers interact more closely with the training companies, and this may influence the safety climate and practice at the training companies and may contribute to keeping the school/training company discrepancies lower for the Swedish students. The Swedish teachers/schools may also select companies that prioritize safety more highly.

In the qualitative study, we found that both Danish and Swedish students identified company- based training as central to practical learning. However, whereas the Swedish students emphasized the right to voice their concerns about safety, the Danish students 
tended to describe this as more of a dilemma. They referred to safety as an expense from the point of view of their employer and were reluctant to criticize poor safety arrangements. Keeping good relations with the firm was seen as important to keep the apprenticeship. Swedish teachers described themselves as the students' advocates, whereas Danish teachers said they had no direct means of influencing the students' conditions at company- based training, referring them instead to trade unions or their employers. Even though Danish students were trained in specific health and safety courses during VET, they had few 'scaffolding rules' to help them when they started to work at the training company. Differences in the organization of the VET systems in Sweden and Denmark thus may illuminate the differences in the safety climate as per the survey data, where Danish students reported a greater difference between schoolbased and company- based training in their safety climate ratings.

The Swedish model of VET can be described as a 'student curriculum' where the role as student workers refers to taking part in company- based training in a firm as a student, not as an employee. In the Danish system, an 'apprentice curriculum' is promoted, where the students' status as employees in the training company strengthens their participation as being one of the workers. This is suggested by the Danish students referring to 'speaking up' and 'saying no' as something that could result in them losing their apprenticeship or damaging relations with co-workers, even if speaking up could also be seen as part of the norm of 'taking care of one self'. With the Swedish students the same issues were referred to in relation to the overall norm of egalitarian participation, to the importance of respecting individual differences, and the right to voice their opinions. These differences underline the notion of connectivity in VET as an essentially collective process where learner agency is embedded in the educational context (Billett 2008). Focus is directed away from individuals' intelligence or ability to manipulate knowledge towards contexts of social interaction and participation. This may also explain why Danish students rated the top manager of the training company as more important than the VET teacher in their training to become as skilled craftsperson, while the opposite was found among Swedish students. Within the organizational practice of the apprenticeship model of workplace training, the Danish connectivity model seems to promote a form of safety learning with less use of 'scaffolding rules' compared to the Swedish model.

The notion of developing from novice to expert is pertinent here, especially in relation to workplace safety learning. According to Dreyfus and Dreyfus (1986), moving beyond rules and using discretion is an indicator of development from novice to expert which implies enactments of different forms of 'knowings'. Within workplace safety and health studies, however, violation of rules is generally considered to be counterproductive for health and safety at the workplace; breach of safety rules and procedures increases the risk of injuries and accidents (c.f. Hale and Borys 2013; Bieder and Bourrier 2013). Applying a connective model of learning facilitates understanding of the complexity of rules in relation to VET learning: on 'scaffolding rules' as drawing attention to students' role as novice and less experienced and their need for extra protection, and on how these same rules can prolong the practical and embodied processes of learning. Different forms for participation imply different notions of belonging and becoming in the process of moving towards qualified participation. Different connective models of learning therefore support different forms of enactment of safety 'knowings'. 
Based on our analysis, it can be argued that in the Swedish connectivity model, students are working as novices for a longer period of time. They therefore move more slowly from novice to expert knowing compared with the Danish students. According to Chan (2013), identity as a tradesman is enacted through one's own identification as well as one's colleagues' understanding of the novice, referring to: "(T)he conferment of various progressive occupational identity way-markers by others, before apprentices' actual self-acceptance of each conferred job-role, is therefore an important outcome of occupational identity formation through apprenticeship" (Chan 2013, 368). Differences in connectivity models may contribute to our understanding of how different modes of belonging as well as identity influence how students are provided with skills to know the difference between 'idealized practices' at school and enactment of safety 'knowings' at the training company.

As described above, Swedish students were on average four years younger than the Danish students which could possibly be of importance with regard to safety behaviour because it might influence cognitive and emotional maturity. However, none of the questionnaire scales showed any age-related effect; there was for instance no difference in the means of the youngest Danish respondents and the oldest (data not shown). Furthermore, the expected direction of an age-related effect would be that the older students (the Danish) were more safety aware and more willing to voice concerns than younger students (the Swedish).

\section{Conclusions}

The article has pursued an analysis of how different institutional models of VET possibly translate into differences with regard to students' sense of belonging, occupational identity and safety learning.

In relation to the first question posed, it has been shown that connections between school-based and company based-training are organized differently in the Swedish and Danish institutional models of VET. These include different forms of employer/ company involvement in VET in the two countries, and the different status of students (as students or apprentices). The organization of health and safety training also differed as the Swedish model pursued an integrated model of training, whereas the Danish model taught specialized health and safety training courses. Such courses may enhance theoretical knowledge about health and safety, i.e. 'idealized models', and could thus contribute to a sense of contradiction in relation to more pragmatic safety practices at the training company. While working in the company, the Swedish students' safety is the joint responsibility of the school and the training company, whereas the Danish apprentices' safety is the responsibility of the training company alone. As Swedish teachers supervised students while working in the training company, they described themselves as the students' advocates, also in relation to safety. The Danish teachers had no means of influencing or helping students during company- based training, but could referre them to the trade union or employer if needed. Two different models of connectivity was thus promoted with these different organizational practices.

Regarding our second question, Danish students rated the training company supervisor as being significantly more important in relation to the students' efforts to become 
skilled workers than did the Swedish students. Students in both countries identified company- based training as central to their practical learning. Whereas Swedish students emphasized their right to voice their opinion if they had concerns with regard to safety, Danish students described this as a dilemma since their employer could be seen to view safety as an expense. These results indicate differences between the two countries in connectivity and forms of belonging in the training companies.

In relation to question three on how different modes of 'knowings' are enacted, differences in connectivity models between Danish and Swedish VET coincided with different forms of participation in the community of practice at the training companies. These may have implications for students' sense of belonging, occupational identity, and safety learning. The connectivity model within a Danish apprentice curriculum was related to a sense of belonging enacted through practices at work, which made it more difficult to employ arguments about safety learned in the theoretical classes at school, but possibly also to more tacit forms of embodied safety practices. The apprentice curriculum were supported by an organizational practice where the students themselves were understood to be responsible for connecting different 'knowings' across the school/training company divide.

The Swedish model of connectivity seems to promote a model of connectivity where training company learning is practiced through 'scaffolding rules', which is supported by legislation according to which training companies and schools are jointly responsible for safety in company-based training. This model of connectivity is based on a form of learning that promotes a prolonged novice period for students, which also is related to Swedish VET students not being eligible for professional work when they leave VET. In the Danish model of connectivity responsibility for students/ apprentices' safety is divided between school and company relative to the educational period. Danish students spend more time working on the school shop floor than the Swedish students, and they are also taught theoretical courses on health and safety. Paradoxically, this might serve to strengthen the sense of contradiction between the school and training company safety climate; a sense of safety standards as an ideal compared to practice as inherently imperfect. At the same time, as the Danish model promotes an apprentice mode of learning that focuses on developing fully trained students upon completion of VET, the movement from novice to expert seems to occur at a faster rate than in the Swedish model. Therefore, a sense of belonging to the company and the development of occupational identity and expert enactment of 'knowings' possibly contribute to the sense of disconnection and fragmentation in safety learning that is more evident among Danish students than among Swedish students. Thus differences in organizational practices may have important implications for the context of safety learning and practices among young construction workers. This, in turn, could help to illuminate one aspect of why we see considerably higher frequency of occupational accidents in the Danish construction industry compared to the Swedish. The findings can contribute to reflexive considerations on how organizational practices promote different forms of safety learning in VET, pointing to the importance of reflecting on how 'scaffolding rules' might increase students and apprentices' safety at work, while also acknowledging the importance of tacit, practical and embodied forms of safety learning within this form of work. 
Open Access This article is distributed under the terms of the Creative Commons Attribution 4.0 International License (http://creativecommons.org/licenses/by/4.0/), which permits use, duplication, adaptation, distribution and reproduction in any medium or format, as long as you give appropriate credit to the original author(s) and the source, provide a link to the Creative Commons license and indicate if changes were made.

\section{References}

Aarkrog, V. (2011). A taxonomy for teaching transfer skills in the Danish VET system. Nordic Journal of Vocational Education and Training, 1(1), 1-13.

Akkerman, S. F., \& Bakker, A. (2011). Boundary crossing and boundary objects. Review of Educational Research, 81(2), 132-169.

Berner, B. (2010). Crossing boundaries and maintaining differences between school and industry: Forms of boundary- work in Swedish vocational education. Journal of Education and Work, 1, 27-42.

Bieder, C., \& Bourrier, M. (Eds.). (2013). Trapping safety into rules. How desirable or avoidable is Proceduralization. Farnham: Ashgate Publishing Limited.

Billett, S. (2008). Subjectivity, learning and work: Sources and legacies. Vocations and Learning, 1(2), 149171.

Bøje, J. D., Beck, S., \& Winum, H. (2014). Learning to stay in school. Nordic Journal of Vocational Education and Training, 4, 1-16.

Bryman, A. (2004). Social research methods (2nd ed.). Oxford: Oxford University Press.

Bryman, A. (2006). Integrating quantitative and qualitative research: How is it done? Qualitative Research, $6(1), 97-113$.

Busemeyer, M. R., \& Schlicht-Schmälzle, R. (2014). Partisan power, economic coordination and variations in vocational training systems in Europe. European Journal of Industrial Relations, 20(1), 55-71.

Chan, S. (2013). Learning through apprenticeship: Belonging to a workplace, becoming and being. Vocations and Learning, 6, 367-383.

Creswell, J. W. (2003). Research design: Qualitative, quantitative, and mixed methods approaches (2nd ed.). Thousand Oaks: Sage.

Dreyfus, H. L., \& Dreyfus, S. E. (1986). Mind over machine. The power of human intuition and expertise in the era of the computer. New York: The Free Press.

Education Act (2010). (In Swedish: Skollag) SFS nr: 2010:800, Utbildningsdepartementet 2010-06-23 (http://www.riksdagen.se/sv/Dokument-Lagar/Lagar/Svenskforfattningssamling/Skollag-2010800_sfs2010-800/?bet=2010:800\#K15 accessed November 2016).

Eurostat. (2010). Health and safety at work in Europe (1999-2007) - a statistical portrait. Social Affairs and Equal Opportunities: European Commission Employment http://ec.europa. eu/eurostat/documents/3217494/5718905/KS-31-09-290-EN.PDF/88eef9f7-c229-40de-b1cd-43126bc4 a946.

Fuller, A., \& Unwin, L. (2003). Fostering workplace learning: Looking through the lens of apprenticeship. European Educational Research Journal, 2(1), 41-55.

Fuller, A., \& Unwin, L. (2013). Introduction: International perspectives on apprenticeship. In A. Fuller \& L. Unwin (Eds.), Contemporary apprenticeship. International perspectives on an evolving model of learning (pp. 1-8). London: Routledge.

Gherardi, S. (2006). Organizational knowledge: The texture of workplace learning. Malden: Blackwell Publishing.

Gherardi, S. (2010). Community of Practice or practices of a community? In S. J. Armstrong \& S. V. Fukami (Eds.), Management learning, education and development (pp. 514-530). London: SAGE.

Gherardi, S., \& Nicolini, D. (2002). Learning a trade: A culture of safety in practice. Organization, 9(2), 191223.

Gherardi, S., Nicolini, D., \& Odella, F. (1998a). What do you mean by safety? Conflicting perspectives on accident causation and safety Management in a Construction Firm. Journal of Contingencies \& Crisis Management, 6(4), 202-213.

Gherardi, S., Nicolini, D., \& Odella, F. (1998b). Toward a social understanding of how people learn in organizations: The notion of situated curriculum. Management Learning, 29(3), 273-297.

Griffiths, T., \& Guile, D. (2003). A connective model for learning: The implications for work process knowledge. European Educational Research Journal, 2(1), 56-73. 
Grill, M., Grytnes, R., \& Törner, M. (2015). Approaching safety in the Swedish and Danish construction industry: Professionals perceptions of safety culture differences. Safety Science Monitor, 2(6), 1-17.

Grytnes, R. (2017). A sense of security: Carpenter apprentices handling uncertain and dangerous work tasks. Ethnos: Journal of Anthropology. doi:10.1080/00141844.2017.1282972.

Guile, D., \& Griffiths, T. (2001). Learning through work experience. Journal of Education and Work, 14, 113131.

Hale, A., \& Borys, D. (2013). Working to rule, or working safely? Part 1: A state of the art review. Safety Science, 55, 207-221.

Hodkinson, P., Biesta, G., \& James, D. (2008). Understanding learning culturally: Overcoming the dualism between social and individual views of learning. Vocations and Learning, 1, 27-47.

Jørgensen, C. H. (2015). Challenges for work- based learning in vocational education and training in the Nordic countries. In S. Bollinger (Ed.), Working and learning in times of uncertainty (pp. 159-171). Rotterdam: Sense Publishers.

Juul, I., \& Jørgensen, C. H. (2011). Challenges for the dual system and occupational self- governance in Denmark. Vocational Education and Training, 63(3), 289-303.

Kines, P., Lappalainen, L., Mikkelsen, K. L., Olsen, E., Pousette, A., Tharaldsen, J., Tómasson, K., \& Törner, M. (2011). Nordic safety climate questionnaire (NOSACQ-50): A new tool for diagnosing occupational safety climate. International Journal of Industrial Ergonomics, 41(6), 634-646.

Lave, J., \& Wenger, E. (1991). Situated learning. Legitimate peripheral participation. Cambridge: Cambridge University Press.

Murtonen, M., Sahlström, S., Tynjälä, P. (2009). Educating novices at the workplace: Transformation of conceptions and skills of students on a metal industry course. In Stenström, M.-L., Tynjälä, P. (eds) Towards integration of work and learning. Netherlands: Springer Science+Business Media, 2009, 93113.

Nielsen, M. L. (2012). Adapting 'the normal' - Examining relations between youth, risk and accidents at work. Nordic Journal of Working Life Studies, 2(2), 71-85.

Norris, N. (1997). Error, bias and validity in qualitative research. Educational Action Research, 5(1), $172-176$.

Persson, T. D., \& Hallqvist, A. (2014). Nordic-VET: The future of VET in the Nordic countries. Nord-VET: Report B Sweden. The current state of the challenges for VET in Sweden http://nord-vet. dk/indhold/uploads/Report-1-B-Sweden-2014-12-01.pdf.

Pisaniello, D. L., Stewart, S., Jahan, N., Pisaniello, S. L., Winefield, H., \& Braunack-Mayer, A. (2013). The role of high schools in introductory occupational safety education - The teachers perspectives on effectiveness. Safety Science, 55, 53-61.

Poortman, C. L., Illeris, K., \& Nieuwenhuis, L. (2013). Apprenticeship: From learning theory to practice. Journal of Vocational Education and Training, 63(3), 267-287.

Responsibility for the pupils' work environment (2013). (In Swedish: Ansvaret for elevernas arbetsmiljö). Web: http:/www.skolverket.se/fran-skola-till-arbetsliv/apl/ansvar-for-elevernas-arbetsmiljo-1.196819. Accessed Dec 2016.

Schaap, H., Baartman, L., \& de Bruijn, E. (2012). Students' learning processes during school- based learning and workplace learning in vocational education: A review. Vocations and Learning, 5, 99-117.

Somerville, M. (2006). Subjected bodies, or embodied subjects: Subjectivity and learning safety at work. In S. Billet, T. Fenwick, \& M. Somerville (Eds.), Work, Subjectivity and learning (pp. 37-52). Dordrecht: Springer.

Spangenberg, S., Baarts, C., Dyreborg, J., Jensen, L., Kines, P., \& Mikkelsen, K. L. (2003). Factors contributing to the differences in work related injury rates between Danish and Swedish construction workers. Safety Science, 41(6), 517-530.

Stenström, M.-L., \& Tynjälä, P. (eds) (2009) Towards integration of work and learning. Netherlands: Springer Science+Business Media, 93-113.

Swedish National Agency for Education (2011). (In Swedish: Skolverket) Läroplan, examensmål och gymnasiegemensamma ämnen för gymnasieskola. 3.2 BYGG- OCH ANLÄGGNINGSPROGRAMMET, 19-20. http://www.skolverket.se/laroplaner-amnen-och-kurser/gymnasieutbildning/gymnasieskola/sok-amnenkurser-och-program/program.htm?lang=sv\&programCode=ba001.

Tanggaard, L. (2007). An exploration of students' own explanations about dropout in vocational education in a Danish context. Journal of Vocational Education and Training, 65(3), 422-439.

Tashakkori, A., \& Teddlie, C. (Eds.). (2010). Mixed methodology: Combining qualitative and quantitative approaches. Thousand Oaks: Sage.

Taylor, A., \& Freeman, S. (2013). 'Made in the trade': Youth attitudes toward apprenticeship certification. Journal of Vocational Education and Training, 63(3), 345-362. 
Tómasson, K., Gústafsson, L. (2011). Fatal occupational accidents in the Nordic countries 2003-2008: Nordic Council of Ministers.

Training Agreement between the social partners to the labour market (2006). (In Swedish: Yrkesutbildningsaftal mellan arbetsmarknadens parter), BYN http://www.byn.se/uploads/BYN\%20 allmant/yrkesutbildningsavtal byggnadsavtalet 2006-03-27.pdf.

Tynjälä, P. (2009). Connectivity and transformation in work-related learning - Theoretical foundations. In M.L. Stenström \& P. Tynjälä (Eds.), Towards integration of work and learning (pp. 11-37). Netherlands: Springer Science+Business Media.

Tynjälä, P. (2013). Toward a 3-P model of workplace learning: A literature review. Vocations and Learning, 6 , 11-36.

Vocational Education Act (2013). (In Danish: Bekendtgørelse af lov om erhvervsuddannelser). LBK 439 https://www.retsinformation.dk/Forms/R0710.aspx?id=152697 - Afs1https://www.retsinformation. $\mathrm{dk} /$ Forms/R0710.aspx?id=146491.

Zitter, I., Hoeve, A., de Bruijn, E. (2016) A design perspective on the school-work Boundary: A Hybrid Curriculum Model. Vocations and Learning, doi:10.1007/s12186-016-9150-y.

Regine Grytnes works as a researcher at the Department of Occupational Medicine, Regional Hospital West Jutland, Herning, Denmark. She received her Ph.D. in anthropology on the topic of safety at work among carpenter apprentices in Denmark. Her research interests' covers issues related to safety and risk at the workplace, workplace practice, vulnerable/ young workers and safety culture in a variety of work settings.

Martin Grill is a psychologist and a doctoral student at Department of Public Health and Community Medicine, Gothenburg University on a project on Safety in the Construction Industry in Denmark and Sweden.

Anders Pousette Senior Lecturer, Ph.D. at the Department of Psychology, University of Gothenburg. His research interests cover issues related to working life, health and safety and safety culture from the perspective of organizational psychology, within areas related to the health care, patient safety and occupational safety.

Marianne Törner Professor, Ph.D. is the leader of the research team 'Safety, Organization and Leadership' at Department of Public Health and Community Medicine, University of Gothenburg. Her research covers safety and security in organizations from the perspective of organizational psychology, including safety climate and safety culture in relation to occupational safety, patient safety, information security, airdrome security and aviation safety.

Kent J. Nielsen psychologist, Ph.D. and a senior researcher at the Department of Occupational Medicine, Regional Hospital West Jutland, Herning, Denmark. His is leading a research team on 'Safety and the prevention of injuries at work', and his research has been focusing on safety culture and interventions within a number of different industries with a special focus on organizational leadership and organizational psychology. 